\title{
THE HUNTING CLUB OF PETRAS GRIŠKEVIČIUS AND THE CONSOLIDATION OF THE LITHUANIAN NOMENKLATURA
}

\author{
Saulius Grybkauskas
}

ABSTRACT This article focuses on informal practices and, in particular, hunting, which was perhaps the most important 'extra-curricular' activity of the nomenklatura. Hunting became an excellent platform for a new secretary to establish his authority in consolidating the nomenklatura, which was quite fragmented for many years after the death of the head of Soviet Lithuania A. Sniečkus (1903-1974). This article analyses the composition of the hunting clubs of the authorities, their organisation and their leadership in informal activities, and claims that the hunt served the interests of the Soviet Lithuanian nomenklatura, because it allowed the leader of the Soviet republic to structure and consolidate his clientele.

By manipulating the composition of the most important - first - hunting club, into which people close to him were introduced, but ignoring the possible contenders for the informal leaders, Griškevičius took over control of the members of this hunting club. He first introduced the regulations of the first club of nomenklatura hunters. The 'normalisation' of hunting was an effective strategy which allowed Griškevičius to establish his authority and power, limiting and restricting the potential of the grouping of the Lithuanian nomenklatura. The consolidation of the nomenklatura not only served to strengthen Griškevicius in the post of the new leader, but also lowered the possibilities for the centre's intervention in the management of the republic.*

Research into personal networks is important for the analysis of political systems, because they highlight characteristics of the system. According to the traditional view, informal relationships and their conditioned activities 'outside the borders of the system' were accompanied by negative factors such as corruption and bribery. Nevertheless, researchers of authoritarian regimes notice the positive

* This research was carried out with financing from the project of the Research Council of Lithuania 'Invisible society of Soviet-era Lithuania: The revision of distinction between systemic and nonsystemic social networks'. 
value of informal implications, especially vertical. For example, Ronald Wintrobe affirms that it was important for the Soviet regime, as well as for any authoritarian system, to secure vertical links. In the opinion of another researcher of Soviet hierarchy and social networks John P. Willerton, political patronage was a mechanism facilitating the formulation of policies and their realisation, ${ }^{1}$ while the networks helped the USSR's government to influence processes in the periphery of the country. ${ }^{2}$

In his book about the importance of personal networks in Soviet management, Willerton devotes a whole section to the rule of the LCP CC first secretary P. Griškevičius. In his opinion, the behaviour of Griškevičius in Soviet Lithuania reflected the activities of Leonid Brezhnev in Moscow. Similarly, as the latter formed around himself a circle of reliable clients, Griškevičius advocated people close to him. ${ }^{3}$

Nevertheless, affirming the strengthening of the personal network of Griškevičius when he became the secretary of the republic after the death of Sniečkus, Willerton does not divulge more broadly the political mechanisms that allowed him to establish himself in this post. Shedding light on the personnel policies of Griškevičius and the protection of his clients in government posts, Willerton does not discuss informal practices that could have been an important condition for the implementation of his personnel policies. I think that deeper study of these informal practices may reveal to us a wider view, which should focus not only on the leader of the republic, implementing Moscow's political programme, but also on the local nomenklatura surrounding him which could keep track not only of Moscow's issued resolutions, but also implementing the agenda of their own perceived interests in the republic. This article focuses specifically on informal practices, in particular, one of them, hunting, which was perhaps the most important 'extra-curricular' activity of the nomenklatura.

Why was the restructuring of the republic's government, the consolidation of the recognition of Griškevičius as the new leader, important for the Lithuanian nomenklatura, and how specifically could hunting be helpful in this process? First, after the death of the long-time leader of the republic A. Sniečkus, the Lithuanian

${ }^{1}$ J.P. Willerton, Patronage and Politics in the USSR (Cambridge, 1992), p. 15.

${ }^{2}$ Ibid., p. 15.

${ }^{3}$ Ibid., pp. 161-171. 
nomenklatura became fragmented. The granting of the sign of the Moscow authorities, the 'yarlyk', to Griškevičius did not yet mean that the new leader of the Republic would get the respect and recognition of local actors to prevent tensions and conflicts within the nomenklatura of the republic. Second, informal agreements were important in the management system. Basically, all decisions had to be reconciled by the leaders before submitting them to the institutions with formal political power, the LCP CC secretariat or bureau. ${ }^{4}$ Third, the Lithuanian nomenklatura as the managing corporate layer expressed the social and economic interests of the republic at that time. There is no doubt that its unity was an important category not only in the context of the relationship between the republic's government and society, but also in discussing the republic's government separation (particularism) with respect to the centre. The unity of the republic's leaders was an important factor reducing the possibility of intervention by the centre.

The topic of hunting by the Lithuanian nomenklatura has not specifically been investigated in historiography. Its significance is discussed only in talking about common issues on the theme of the nomenklatura, such as relations or social status. Speaking about the privileges held by the ruling layer and exclusive use, the historian V. Ivanauskas noted that certain social rituals, neighbourhoods, hobbies and family ties united the nomenklatura, and hunting was one of the activities by the nomenklatura helping to establish the exclusivity of its status. Such a repetitive model of social relations between the nomenklatura would establish general norms and values. ${ }^{5}$ This well-aimed hint by V. Ivanauskas about relations among the nomenklatura should be confirmed by empirical material detailing social rituals, including hunting, in the empirical material of archival funds, published memoirs and interviews. Social commonality is certainly relevant, especially when in the words of N. Voslensky the groups of the 'ruling class of the nomenklatura', but it is important to incorporate the links of the nomenklatura into the system, revealing what they meant to the political set-up at that time, in the relations between the centre and the periphery.

${ }^{4}$ For example, presenters during the interview did not remember any vivid discussions of these organs during the meeting, saying that everything had been discussed in advance.

${ }^{5}$ Available on the internet at: $<\mathrm{http} / /$ sovietcase.eu/en/wp-content/uploads/2012/02/ Sovietines-privilegijos_str._2012Vasaris.pdf> [address visited on 3006 2014]. 
The still prevalent negative attitude to hunting in society complicates the possibilities for its investigation. For this reason, comprehensive and detailed stories of former hunters can hardly be possible. All the more because the stories of their participants can basically be the only testimony about their organisation. The documents of the fund of the Lithuanian SSR Nature Conservation Committee stored in the Lithuanian Central State Archives, ${ }^{6}$ allowing one to at least touch on this topic, are extremely meagre: I was unable to find any lists of participants in clubs or any accounts of the organisation of hunts or their course. The archive material is more illustrative, allowing one only to describe the context. Let us say that from the reports of the state hunting farms to the Lithuanian SSR State Natural Committee, one can then determine the hunting areas of the nomenklatura at that time, but I failed to find data on how often hunting took place. It is true that the photographs held in the photographic document section of the archive illuminate the hunts by one circle of government employees, the Second club. The fact that one of the most active members of the club, Feliksas Bieliauskas, was a photography buff, who held the position of head of the board of archives of the Lithuanian SSR Council of Ministers, undoubtedly contributed to the documentation of the hunting. From the photographs taken by Bieliauskas and his colleagues, one can learn about hunting locations, dates, and even the composition of this club.

Due to the very limited archival sources, it is particularly important to publish the memoirs and stories of former players. The study benefited from the published memoirs of the former secretary of the Lithuanian CP CC, and then chairman of the Presidium of the Lithuanian SSR Supreme Council, Vytautas Astrauskas, the vice chairman of the Lithuanian SSR Council of Ministers Vilius Kazanavičius, and the LCP CC secretary Lionginas Šepetys, and interviews about their time hunting, the book by A. Brazauskas Ir tuomet dirbome Lietuvai [And Then We Worked for Lithuania] and his interview with the author of the article in January 2008.

These sources allow us to contribute to investigations into the informal activities and networks of government personalities in historical literature, thus formulating the main proposition of this article: the organisation of government hunts during the Soviet-period

${ }^{6}$ LCVA, f. R-649. 
republic served to strengthen the power of the republic's head, and also to consolidate the Lithuanian nomenklatura. In this article, it is affirmed that the hunting by the Soviet nomenklatura, although not open and resented by part of the public, however, contributed to the consolidation of the Lithuanian nomenklatura, creating even a certain degree of isolation from the centre. A very important moment in the hunting by the nomenklatura was the composition of the participants, i.e. who hunted with whom. The composition of the hunters determined the content of communication and the limits of possible arrangements. For example, if in the company of the Soviet republic's leader's hunt there were constantly the same representatives of union or central institutions, we could not only suspect, but affirm, that the expectations and identity of the leader were oriented toward the Kremlin; of course, if there is no proof that he did so in order to extract funds for the republic. Therefore, the article analyses the composition of the government hunting clubs, their organisation and leadership in this informal activity, and claims that the hunt served the interests of the Soviet Lithuanian nomenklatura because it allowed the Soviet republic leader to construct and consolidate his clientele.

\section{Joining the Club}

'Anyone who wanted to make a career had to hunt, and especially tried to enlist in the first club ... When hunting and partying, many issues were resolved, ${ }^{, 7}$ former long-time rector of Vilnius University Jonas Kubilius (1921-2011) said during an interview. The academician J. Požèla, who was an active member of the nomenklatura club, described the friendly atmosphere during and after hunting in this way:

The hunt was a good thing, one could really relax. Understanding each other very much, one pours out all his problems. Because what does one have to do after the hunt: sit and drink and dine. After one goes fifteen kilometres, and is soaked, then everyone pours out all his problems ... We resolve our problems ... One does not need to call ... even a [party] committee, and while hunting, where one can speak tête-à-tête very easily: how do you think cadre issues in my opinion were resolved ... ${ }^{8}$

${ }^{7}$ Interview by S. Grybkauskas with Jonas Kubilius.

${ }^{8}$ Interview by S. Grybkauskas on 11 June 2013 with the academician Juras Požèla. 
The possibility of an accelerated career, understanding company, and frankly speaking colleagues were sufficient reasons to become a hunter, so it did not take a long time to attract Party and Soviet workers. Nevertheless, there were efforts to 'include' colleagues in the hunt. Even before accession, there was an attempt to create an interest in hunting, to awaken the 'nature of the hunter'. The proposal to join the club was accompanied by the gift of a hunting rifle, and we might also suspect that a better place was chosen in the hunting tower or in the queue for leisure hunting.

The tradition of donating a hunting rifle to the supervisor/leader goes back to the times of the leader of the revolution Vladimir Lenin, who was an avid hunter. The manufacturers of Tula arms gave him a hunting rifle and an ammunition production mechanism. ${ }^{9} \mathrm{~A}$ hunting rifle was awarded to the dictator Stalin at the Twenty-seventh Congress of the All-Union Communist Party (Bolshevik) in 1934 on the occasion of his 50th birthday.

The LCP CC first secretary Peter Griškevičius received a hunting rifle from his colleagues as a 50th birthday gift. He is immortalised with the weapon in a photo in the Širvintos district next to Kostas Glikas, the influential chairman of the Lenin collective farm in the Šakiai district, ${ }^{10}$ who had excellent relationships not only with the Lithuanian nomenklatura, but also with the commanders of the military units deployed in the republic. This gift was very symbolic, because Griškevičius celebrated his anniversary in July 1974, only a few months after his appointment as head of the republic. The bestowal of the gun was like an informal transfer of regalia to the new manager, and the offer not only to be a formal leader, but also as the recognised leader of the group. The photo in the summer of 1974 is the first one in which Griškevičius is immortalised with a gun. Remembering the words of Sofija Griškevičiene that her husband 'only' inherited hunting from A. Sniečkus, we can suspect that from this date he either began hunting or became a more ardent hunter. The list of hunting trophy winners supports this conjecture. In a hunting competition in 1978 in Vilnius, Griškevičius won second place, 'exhibiting' the horns of the European moose shot in

${ }^{9}$ Available on the internet at: $<$ http://shotgun.com.ua/fire/lider_guns.html $>$ [address visited on 0511 2014].

${ }^{10}$ LCVA, Photo document section. SV number 0-079592. 
1974. ${ }^{11}$ In previously held competitions (the list goes back to 1968) for hunting trophies, the name of Griškevičius is not mentioned. So it may be that the rifle that was received as a gift was the start of good hunting, both in the direct recreational, and in the figurative social sense.

In the recollections of L. Šepetys, his LCP CC secretary colleagues gave him a hunting rifle on the occasion of his 50th birthday. In his opinion, his first hunt was by chance successful: the shot 'incidental' boar inspired the passion of a hunter, and he was an active hunter until the end of the Soviet period:

And I became a hunter through absurdity, through stupidity ... On the occasion of my fiftieth birthday, my fellow secretaries gave me a rifle. And before that I had the very worst opinion about hunting. I used to say, why do you travel to the forest, put on rubber boots and drink there? Drink in a café, it is more convenient. I received a gun, and, I remember, in the autumn they invited me to a hunt, when the autumn was beautiful, but one could already hunt wild boar. Well, I went, thinking like that with a gun, and shot a boar that came out for me. I shot and he fell. I was infected like that. ${ }^{12}$

The 'last hunt' of Šepetys, already in the period of the national revival, is also symbolic, because it highlights that he did not have a predilection to hunt so much as the desire to communicate and be a member of the club. In his recollections, at the end of the Soviet era, a trip to the hunt was carried out in a Latvia minibus, and during these trips, he was criticised by his colleagues for inappropriate actions, his indulgence to Sajūdis members. ${ }^{13}$ This demonstrates the 'utilitarian' exploitation of hunting, i.e. it shows that social relations were the most important factor for him. There is no doubt that, with a great desire to hunt, the criticism could have gone over the head, but the changing political situation (the beginning of the public condemnation of hunting), and the 'hunter friends' losing influence ${ }^{14}$ reduced the value of this active recreation.

${ }^{11}$ See the entry on the internet: $<$ http://www.medzioklekaunas.lt/sites/default/ files/files/MEDZIOKLES\%20TROFEJU\%20REJESTRAS\%202013.pdf> [address visited on 3006 2014].

${ }^{12}$ Interview by S. Grybkauskas with Lionginas Šepetys.

${ }^{13}$ Ibid.

${ }^{14}$ The 2A circle member academician J. Požèla related about the despair of the senior nomenklatura expressed during the hunt by another member of the 'elite' circle of hunters. By his assertion, towards the end, the people complained about the uncertain work prospects, that it was difficult to find a new job. See interview by S. Grybkauskas with Juras Požèla. 
Not all Party personnel accepted the offer to become hunters. There were those who tried to maneuver, and searched for excuses for not participating actively in hunting. For example, Vladislovas Mikučiauskas, the former head of the Kaunas city and Party City Committee first secretary, having received an 'Iz' hunting rifle as a gift, was also invited to join a club. However, as he asserts, he disliked hunting, and found a way to avoid shooting: when the leaders of the republic arrived, Mikučiauskas would take a camera to the hunt, and this allowed him 'not to fall out' of the hunting circle. As Mikučiauskas relates, the leader of the republic Griškevičius did not travel to hunt in the Kaunas district very often, about once a year, and he joined in 'with a camera'.

Vladimir Beriozov, the head of the LCP CC Organisational Department of Party Work, and from the end of 1988 LCP CC second secretary, was able to resist the passion of the hunter. He relates that once he was persuaded to hunt, and unexpected success accompanied it. Just like Lionginas Šepetys, the first time he shot a large boar. According to Beriozov, he and his wife were in a tower when a boar appeared, and he fired accurately. If these stories of Šepetys and Beriozov are not just boasting, we can suspect that in the attempt to draw colleagues into the hunting club, not only were weapons donated, but also favourable conditions for hunting were created.

Often people became hunters after a direct exhortation or even 'assignment' from superiors. For example, Aleksandras Drobnys, the chairman of the Lithuanian SSR Planning Committee, having to welcome a functionary from Moscow and take him hunting, became sick, so he 'ordered' his subordinate Algirdas Brazauskas, the first deputy chairman of the Lithuanian SSR Planning Committee, to go hunting instead of him. ${ }^{15}$ From this point to the last winter of his life, during which Brazauskas regretted that he could not go into the woods, he became an 'inveterate' hunter. At the urging of Juozas Matulis, the president of the Lithuanian SSR Academy of Sciences, Juras Požèla, the director of the Semiconductor Institute and vice president of the Lithuanian Academy of Sciences, began hunting. ${ }^{16}$

${ }^{15}$ R. Sakalauskaite, 'Nenugalimoji prezidento aistra', Žmogus laiko taikinyje. Algirdas Brazauskas draugu ir oponentu akimis, V. Kavaliauskas (compiler) (Vilnius, 2013), p. 393.

${ }^{16}$ Interview by S. Grybkauskas with J. Požèla. 
'Persuasion' to hunt was an offer to become an 'insider', that is, to have a hobby in common which could be discussed together. However, this did not mean accession to the same club in which the leader was. In this way, Brazauskas for a long time hunted in the second club, when Drobnys was an active hunter of the first club. Juras Požèla also could not often join in the hunt with Juozas Matulis, because the latter hunted in the first club with A. Sniečkus. Požèla was a member of the 2A club, which Lionginas Maksimovas led.

So, in summary, we can say that the hunting by members of the government was not such an 'incidental' occupation, when the leaders already having such a hobby gathered to hunt. It would seem that there is nothing special if colleagues join clubs based on hobbies: some hunt, others fish or play chess. Somewhat differently, Party personnel would find the hobby to hunt attached to their positions. For example, V. Astrauskas describes his first hunt very vividly. According to him, while he was still working as the Šeduva district LCP secretary, A. Sniečkus and M. Šumauskas arrived, and said: let's have a hunt. A small one. My God, I am not a hunter. I was thinking, what should I do? So I asked for advice from some hunters. I did not have a gun. So they gave me a rifle that had been confiscated by the police, and they came together with Šmauskas. We hunted a little in the woods. I was standing, and a boar ran past me towards Šmauskas. Šumauskas fired and shot the boar. He asked why I did not shoot? I said that somehow I did not notice it. I overlooked it. I deliberately did not shoot, because I was not a hunter. I thought I would miss. ${ }^{17}$

Thus, it was somewhat different: 'big people' were invited, 'drawn in', or themselves sought ways to fit in, to join the hunting club of the leading workers. Hunting was not only one of the many 'extra-curricular' hobbies or activities. It is doubtful whether the hobby to hunt spread 'naturally' in the networks of the nomenklatura as fashions, expressions of lifestyle, or even topics of discussion and speaking postures spread in social groups. These moments in social life are often repeated instinctively. Hunting was about intuitively or even strategically understanding its benefits, even though its main value was not the catch, but the capital accumulated in social networks.

${ }^{17}$ Interview by S. Grybkauskas with V. Astrauskas. 


\section{The Composition of Clubs and Hunting Areas}

According to an assertion by academician J. Požèla, during the Soviet period there were three hunting circles made up of members of government structures, which he described as: 'one [the first], the second and the other second'. ${ }^{18}$ The registration documents of the hunting areas and the animals they contained kept in the State Committee for Nature Fund confirm this, marking 'the other second' as the $2 \mathrm{~A} \mathrm{club}^{19}$. As Požèla related, Lionginas Maksimovas, the head of the LCP CC Industry and Transport Department, led this club. Juozas Kuolelis, the head of the LCP CC Propaganda and Agitation Department, was a member of the club. Požela called himself an 'intruder' from the Academy of Sciences, while the majority of hunters were leaders, ministers of Lithuanian SSR industrial ministries. According to Požèla, one of the most active hunters in the circle was Minister Semionenka of the Ministry of Local Industry. ${ }^{20}$ Hunting played a very important role in his career. In the recollections of V. Astrauskas, Sniečkus entrusted him, as the head of the LCP CC Organisational Party Work Department, to find a 'normal Russian' for the duties of second secretary of the Vilnius City Party Committee. Astrauskas knew Semionenka already from the times of his work in Radviliškis, when, according to Astrauskas, he 'would assist' the sisters of Griškevičius' wife Sofija living in Radviliškis 'to obtain' scarce goods. After coordinating his candidacy with the Vilnius Party first secretary Griškevičius, Astrauskas presented Semionenka's candidacy to Sniečkus. The latter responded immediately to the words of the LCP CC head: 'Oh, that bald one.' Sniečkus remembered Semionenka from a hunt in the Radviliškis district. ${ }^{21}$

The lack of documentation on the nomenklatura's hunts hinders us in the accurate setting of the composition of the clubs. When changing positions, functionaries were able to 'migrate' from one club to another, while others, such as Požèla, remained in the same $2 \mathrm{~A}$ club until the end of the Soviet period. In his recollections, Brazauskas was in the first club, but in fact he was 'promoted' to the first only later, when he became LCP CC secretary, and even then not immediately. As we can see from photos of the hunts,

\footnotetext{
${ }^{18}$ Interview by S. Grybkauskas with the academician J. Požèla.

${ }^{19}$ Account of hunted animals and birds in 1983.

${ }^{20}$ Interview by S. Grybkauskas with the academician J. Požèla.

${ }^{21}$ Interview by S. Grybkauskas with V. Astrauskas.
} 
in December 1977 and January 1978, when he was already LCP CC secretary, he still hunted in the areas of the second club with its members. ${ }^{22}$ In the photographs of F. Bieliauskas stored in the LCSA, we can see him hunting with the second club. The members of this club were the mentioned F. Beliauskas, vice-president of the Lithuanian SSR Supreme Council, and later all-union personal pensioner Jonas Vildžiūnas, the Lithuanian SSR Public Utilities minister K. Plechavičius, his deputy and the brother of Feliksas Bieliauskas Vytautas, the Lithuanian SSR State Nature Committee chairman K. Giniūnas, the Lithuanian SSR minister of agriculture Medardas Grigaliūnas, the Lithuanian SSR Fisheries Board chief J. Baravykas, the Lithuanian SSR Light Industry minister Ramanauskas, the LCP CC Administrative Organs Department head Aleksandras Builys, the LCP CC Affairs manager B. Aliukonis, the Lithuanian SSR KGB first deputy chairman Pavel Voroshilov, ${ }^{23}$ and the most influential hunter of the second club was the LCP CC second secretary sent from Moscow Valery Charazov. ${ }^{24}$ The fact that these individuals are perpetuated in not one, but several hunts by the club, shows that they were not guests, but members of the club.

We can guess that his acquaintance with Charazov in the hunting of the second club was very important for the further career of Brazauskas. In the recollections of Charazov, for issues of concern, which were in the competence of the Lithuanian SSR Planning Committee, he addressed Brazauskas directly, rather than as befits formally, the institution or its director, A. Drobnys. In 1977 when the question of a new LCP CC secretary of industry and construction arose, Charazov supported the candidacy of Brazauskas. ${ }^{25}$

The narration of Astrauskas confirms these words of Charazov. According to him,

Brazauskas was a man of his word. If you asked him for something, he would ponder it and say that it was impossible ... If he said good, that meant you knew it would be done. Charazov was convinced of this a few times. He travelled to the districts, in this way he would get all kinds of requests, one of them would be the allocation of additional funds or material goods, or construction ... And as

${ }^{22}$ See the 31 December 1977 photograph from the Girele forest in the Kaišiadorys district, LCVA, photo document section, storage unit numbers 0-067967, 0-067986.

${ }^{23}$ See the 31 December 1977 photograph from the Girele forest in the Kaišiadorys district, ibid., 0-067969.

${ }^{24}$ See the photos of the 27 September 1980 hunt of circle, ibid., 0-067965, $0-067966$.

${ }^{25}$ Interview by S. Grybkauskas with V. Charazov. 
far as I know, he addressed not Drobnys but Brazauskas. And he did. There were a few times, perhaps in deference, that the second [secretary] applied. And he [Charazov] valued him [Brazauskas] very much. He [Charazov] said to me: this is a man with great prospects. ${ }^{26}$

After becoming LCP CC secretary, Brazauskas went over to the first club, which consisted not of the highest functionaries, but of those close to Griškevičius. Some of them were related by family ties. For example, one member of the club was the son of Griškevičius, Aloyzas, whom the LCP CC and the Lithuanian SSR minister of health appointed deputy minister 'under pressure' from his father. According to the person in charge of cadre questions, the LCP CC Organisational Party Department head, V. Astrauskas, he still tried to oppose Griškevičius, saying that 'Aloyzas is a good man,' but one should not appoint him deputy minister; however, he did not succeed in convincing the first secretary to change his position. The appointment of Aloyzas Griškevičius as deputy minister was a moment of political nepotism, repeating in the republic events in Moscow. Brezhnev also did not shy away from appointing as heads of institutions not only his acquaintances from their work in Dnepropetrovsk or Moldova, but also members of his family. We should not view the participation of Griškevičius in the first hunting club as some kind of 'Lithuanian exclusivity', because the sons of the leader of socialist Hungary also participated in the most important club during hunts in a very similar way. But there is a crucial difference: the sons of J. Kadar and other Hungarian functionaries were only guests of the hunts, ${ }^{27}$ while A. Griškevičius was a real member.

According to Požèla, not all ministers were members of the $2 \mathrm{~A}$ club headed by Maksimovas. According to him, the minister of industry belonged to the first club. Knowing that Petras Mickūnas, the brother-in-law of Brazauskas, headed the Lithuanian SSR Ministry of Industry, we can immediately see here the use of family ties for becoming a member of the first club.

In addition to Petras and Aloyzas Griškevičius, A. Brazauskas and P. Mickūnas, in the recollections of V. Astrauskas, other members of the first club were the Lithuanian SSR Planning Committee

${ }^{26}$ Ibid.

${ }^{27}$ G. Peteri, Nomenklatura with Smoking Guns: Hunting in Communist Hungary's Party - State Elite, Pleasures of Socialism. Leisure and Luxury in the Eastern Block, ed. D. Crowley, S.E. Reid (Northwestern University Press, 2010), p. 337. 
chairman Aleksandras Drobnys, the Lithuanian SSR KGB chairman J. Petkevičius, the chairman of the Presidium of the Lithuanian SSR Supreme Council Antanas Barkauskas, Motiejus Šumauskas, and the collective farm chairman Kostas Glikas. The leader of the club was not responsible for 'the technical side of the hunt', i.e. the organisation and collecting drivers; the deputy chairman of the Lithuanian SSR Nature Committee Tursa, who was also a participant in the club, was responsible.

The interview and the memoirs by L. Šepetys supplement the list of members of the first club. According to his assertion, he sometimes travelled to hunts with the first deputy of the Council of Ministers Juozas Bernatavičius. The chairman of the National Radio and Television Committee Jonas Januitis also belonged to the club. In the recollections of Šepetys, Griškevičius liked to ask him about the weather forecast for the day and became angry if the announcers under Januitis 'predicted' the weather incorrectly. ${ }^{28}$

As we can see from photographs of the second club, the leaders of the district in which hunting took place were often invited as guests to the hunts. In the period being researched, secretary J. Greičiuvienè led the Kaišiadorys district, in which the Girelè forest favoured by the second club was. As a woman, she did not hunt, but would come to the forest to visit the high-ranking guests. ${ }^{29}$ In the recollections of V. Astrauskas, the leaders of districts would often join the hunters of the first club as guests. In an interview, he mentions the Panevėžys District Party Committee first secretary Galginaitis, who was often with the hunters, because the first club liked the forests of this district.

In the composition of clubs of Soviet Lithuanian government hunters we can see specifics, because the Party hierarchy of functionaries was not accurately represented in it. In accordance with institutional affiliations and features of official hierarchy, it is difficult to explain why functionaries of different levels of the nomenklatura belonged to one club. For example, the leaders of the republic, the heads of LCP CC departments, and some ministerial-level functionaries, such as the Lithuanian SSR trade minister P. Mickūnas, or the State Committee chairman J. Januitis, belonged to the first club.

${ }^{28}$ Interview by S. Grybkauskas with Lionginas Šepetys.

${ }^{29}$ See the December 1977 photograph from Girele forest, LCVA, photo document section, storage unit number 0-067967. 
It would seem that the most important members of the first club, besides the LCP CC first secretary, had to be the chairman of the Lithuanian SSR Council of Ministers and the second secretary of the LCP CC. For example, the former second secretary of the Latvian Communist Party Vitalii Sobolev, who, like his fellow second secretaries in the republics, was not local, but was sent to the post from Moscow, said that he hunted in the first Latvian nomenklatura circle along with other senior officials. ${ }^{30}$ In Lithuania, the second belonged to the second club, and the poor Lithuanian speaking Juozas Maniušis, only coming to Lithuania after the war, the chairman of the SSR Lithuanian Council of Ministers, to still another club, that of the Council of Ministers. Today, we can only guess the reasons why Charazov and Maniušis were 'separated' from other top leaders. One reason could have been the reluctance of the Lithuanian nomenklatura to admit them to their hunting club, in which informal interaction took place. They could have hampered interaction, because of the threat that news overheard during hunting would be reported to Moscow.

Nevertheless, in the composition of the hunters' kruzhok, we should see not only the 'national' strength of the first secretaries of the republic, Sniečkus, or later Griškevičius, but also a certain posture and choice of the 'Moscow vicars' as the LCP CC second secretaries were called. It is doubtful that after the death of Sniečkus it would have been possible to obviate Charazov, who was at the peak of his power, if he had expressed his wish to hunt in the first club. Here we can suspect the very choice of Charazov: instead of participating in the first club, where he could not be the leader, he chose more immediate interaction with his subordinates-clients. Although Astrauskas, the head of the LCP CC Organisational Party Work Department, was also his direct subordinate, but belonged to the first, and not Charazov's club, he often also hunted in the second club, as photos of these hunts testify. Moreover, by the assertion of Astrauskas, he and the LCP CC affairs manager B. Aliukonis would join Charazov travelling to hunt in the Širvintos district neighbouring Vilnius. According to him, Charazov agreed well with Anatolijus Davidonis, the first secretary of the district, and there were even closer ties with the second secretary of the district, who, as in many cities and districts, was a Russian, Sergei Korovin, as well as with

\footnotetext{
${ }^{30}$ Interview by S. Grybkauskas with Vitalii Sobolev.
} 
the chair of the largest pig complex in the republic, Vasily Dorofeev. In the recollections of Astrauskas, Charazov sometimes said: 'Do not hurt Dorofeev,' implying that they would think about awarding an order to the chairman of the complex, or including him in the list of 'elected' honorable duties. Astrauskas replied that he knew Dorofeev for a long time, since the times of working together in Kupiškis, and really supported him. ${ }^{31}$

Thus, the choice of the second secretary not 'to seek entry' into the first club might not have been a sign of the strength of the first secretary, but his own rational step. While hunting, he interacted with his clients and subordinates, which allowed him to get to know them better, to learn important information in the LCP CC apparatus and the rumours spreading outside it, and to strengthen his authority. The story of Charazov about a failed hunting trip in the Girele forest near Kaišiadorys testifies to the recognition of his authority. In his recollection, after an unsuccessful hunt, with the hunters going 'in single file' through bushes near a bog, a covey of wild boar was flushed out, and while he prepared his gun, the 'catch' escaped. Charazov had to settle for a consolation prize: a woodcarving given to him by the members of the club depicting a hunter sleeping in a tree and boars digging at the tree's roots. However, what is important is that this episode not only testifies to the relations between the members of the club and respect for Charazov, but also to his leadership: he went first and led the 'file' of hunters. It is also worth noting that in the hunting pictures, Charazov is 'not satisfied' with a position on the outside of the group, but usually stands in the middle.

In the recollections of Astrauskas, Charazov was not invited to hunt together with Griškevičius and the first club, but after his departure, the new 'governor-general' N. Dybenko participated more than once. In the recollections of the players at that time, Nikolai Kirilovich, who liked to drink constantly, loudly praised Peter Petrovich, was not an ardent hunter, and 'focused' more 'on the evening party'. In the recollections of S. Griškevičienè, the same Dybenko annoyed Griškevičius with his praise, though mockingly behind his back called 'Peter the Great' by the former head of the Statistical Office K. Lengvinas and others, he liked to be praised. Allegedly, while Griškevičius and his wife were his guests, Dybenko so toadied

${ }^{31}$ Interview by S. Grybkauskas with V. Astrauskas. 
and 'praised to the skies' the merits of Griškevičius, that, not being able to stand it, he interrupted: 'Are we at my house, that you are talking only about me? 32

Good conditions were provided for the hunting of the nomenklatura. They did not have to pay any membership fees, or care for feeding the wild animals or attending hunting courses in order to get the certificate of a hunter or hunter-breeder. Large areas which were looked after by four especially created state hunting farms were singled out for their clubs. Only the nomenklatura clubs had the right to hunt in them. As we can see from the reports of the Sunskai state hunting farm to the Lithuanian SSR State Nature Committee, the forests of the farm were assigned to specific nomenklatura clubs. A club could only hunt in its area, rather than selecting a forest on the hunting farm at its own discretion. The documents of the Nature Conservation Committee at that time reveal what belonged to the hunting of the nomenklatura. In this way, the holdings of the Širvintos state hunting farm stretched to the borders of the Širvintos, Ukmergè, Molètai, Vilnius and Kaišiadorys districts.

The areas of another hunting farm, Šunskai, were in southern Lithuania, in the districts of Kapsukas (now Marijampole), Vilkaviškis, Lazdijai and Alytus. There were five hunting bars in the farm: in Kapsukas, Šunskai, Vilkaviškis, Meteliai and Punia. The domains of the Gulbinai state hunting farm were scattered the most in Lithuania. The hunting bar of Daunorava-Žagare in northern Lithuania, the bars of Lygumai and Papilè in northeastern Lithuania, the bar of Salantai in the Zarasai district, and the bar of Kintai-Norkaičiai on the coast belonged to it. In the middle of Lithuania, in the Panevėžys district, there was the Naujamiestis state hunting farm. ${ }^{33}$

Good conditions were provided for hunting by the nomenklatura. Unlike ordinary clubs, to which areas in one district were assigned, the elite clubs had the possibility to change their hunting locations often, from the forests of Dzūkija and Suvalkija belonging to the Šnskai farm, from the areas of the Širvintos and Gulbinai farms in southeast Lithuania and farm areas, to the former bars of the Gulbinai farms in central, northern Lithuania and on the coast. Apparently, these areas determined to a great extent that even two

${ }^{32}$ Interview by S. Grybkauskas with Sofija Griškevičienė.

${ }^{33}$ Account of hunted animals and birds in 1983, LCVA, f. R-649, ap. 1, b. $967,1.160$. 
hunters from the first club were designated in the trophy register as the hunters taking the first prizes in exhibitions and competitions. The already-mentioned moose horns shot by the collective farm chairman Kostas Glikas in 1985 are in the seventh place in the list of Lithuania's trophies. The former chairman of the Presidium of the Lithuanian SSR Supreme Council Antanas Barkauskas also took first place with his moose horns hunted in 1978. As has been mentioned, the result of the hunting by the LCP CC first secretary Griškevičius was awarded a prize at exhibitions. Aleksandras Drobnys was awarded second place for the moose horns hunted a year earlier than Griškevičius, in 1973. All of them were members of the first club. ${ }^{34}$

The composition of hunters' clubs allows us to interpret the social networks of Griškevičius from the position of structural holes used in the theory of social networks. 'Breaking' the formal hierarchical balance and attracting his clients or even relatives into the first club, the first secretary created a situation where all the game players were associated with him, but not necessarily with one another. This allowed Griškevičius to occupy the position of the most important political mediator and increased the cost of possible 'deviant' behaviour by a nomenklatura member, who could easily be isolated, and perhaps even thrown out of the club. Therefore, a coalition, or even opposition to the LCP CC first secretary, as the leader of the club, based on the flexible horizontal ties of the members of the club, did not form. As we will see in other parts of the article, Griškevičius was able to introduce his own order in the hunting and its regulation, and appoint ('elect') a new leader for the club. As a hypothesis, individual members of the club could have disobeyed these proposals by the leader, but the composition of the club determined that this did not happen, because no one wanted to be isolated.

\section{The Rituals, Agreements and Conflicts of Hunting}

During the year, only one of the hunts of the nomenklatura was ritualised; this was the hunting of deer in the Šiauliai district, occurring in the autumn, at the time of mating, 'rutting'. In the recollections

${ }^{34}$ Entry on the internet: <http://www.medzioklekaunas.lt/sites/default/files/ files/MEDZIOKLES\%20TROFEJU\%20REJESTRAS\%202013.pdf> [viewed on 3006 2014]. 
of Astrauskas, Sofija, the wife of Griškevičius, would travel to it, and once the wife of the chairman of the Lithuanian SSR Supreme Council Antanas Barkauskas participated. ${ }^{35}$ In the recollections of Vanda Klikūnienè, the former second secretary of the Vilnius City Party Committee, the first secretary of the city Vytautas Sakalauskas and his wife Bernadeta would travel to these hunts. On the eve of these events, she would complain to Klikūnienè that she had to participate in them. ${ }^{36}$ During the time of this hunt, the hunters were solemnly escorted into the woods.

However, most hunting took place in a routine manner, 'shooting', and afterwards sitting down at a table in a forest hut. In the recollections of Astrauskas, rarely after hunting did the participants gather outside, on tree stumps by a fire in a glade. Therefore, the get-together after the hunt resembled a regular informal gathering, if of course, the hunting was not organised to mark a functionary's birthday. Photographs in archives show that after the hunt the anniversary person was welcomed. Even after 'routine' hunts, the most successful shooter was proclaimed the 'king of the hunt'. ${ }^{37}$ This was not only an honourable 'title' for the person earning it, but also allowed him to lead the dinner and the drinking after the hunt.

Talking about hunting as an exclusive form of informal interaction among the nomenklatura, we should note not only the hunting and the drinking party that took place after it, but the whole process, starting from its organisation, the journey to it, the hunt, the dinner, and finally the return home. For the leader of the club, organising the hunt, the selection of a site and the agreement on it, was an important form of communication, which allows us today to observe the influence and power of the club members. In addition, in analysing the informal networks, information about who travelled with whom to the hunt is eloquent. So, in the recollections of Astrauskas, Griškevičius always came with his son Aloyzas, while Astrauskas himself usually travelled with other CC secretaries, Brazauskas and Šepetys.

This 'grouping' going to the hunt in one car was important in that even in the sample of a single club there were sufficiently narrow niches of communication, in which serious agreements were possible. Thus, in the recollections of Brazauskas, during a hunt,

\footnotetext{
${ }^{35}$ Interview by S. Grybkauskas with V. Astrauskas.

${ }^{36}$ Interview by S. Grybkauskas with Vanda Klikūnienė.

${ }^{37}$ Interview by S. Grybkauskas with V. Astrauskas.
} 
sitting in one car, the LCP CC secretaries heard the reflections of Griškevičius that they needed to ask Moscow to recall the LCP CC second secretary Charazov to Moscow, and appoint a new one. From A. Barkauskas' book, the narrative of J. Kubilius, and indirectly from interviews with Charazov himself, we can surmise that Griškevičius actually talked about the recall of Charazov in Moscow. It is not clear whether this issue was discussed during hunting, as Brazauskas remembers, but Charazov was 'talked about' during a hunt after his departure from Lithuania, the Lithuanian SSR Council of Ministers vice-chair Vilius Kazanavičius remembers. He claims that during a hunt he heard Griškevičius try to commiserate with the new 'second' Nikolai Dybenko that it was impossible to work with Charazov: a matter was mutually agreed on; however, it was reported to Moscow, and from there totally different information came back. ${ }^{38}$ Kazanavičius remembers that Dybenko then repeated that while he was in Lithuania such things would not happen. ${ }^{39}$

During a hunt, as in any informal activity, not only were agreements achieved, but misunderstandings and conflicts were also avoided. In the account of one unsuccessful hunt, in which women also, including Griškevičienè, participated, the leader of the first club, KGB chairman Juozas Petkevičius, commented ineptly that the catch was poor because women participated, as if recalling the archaic provision that there is no place for women in hunting. It is unclear whether Petkevičius was only joking here, or whether there was behind these words an actual rebuke of Griškevičius, who, in the recollections of his contemporaries, heeded the opinion of his wife Sofija; but these words angered Griškevičius. During the next hunt, Griškevičius declared that the leader of the hunt should be changed, himself 'choosing' Astrauskas. No one objected, or at least did not dare to disagree with the proposal of Griškevičius. It is interesting that when the new leader of the club started to show initiatives, he was also immediately punished. In the recollections of Astrauskas, after being appointed the leader of the club, he began to present plans for where the next hunt would be. But his proposals were stopped by the words of Griškevičius: 'You will skip the next hunt.' With this expression, Griškevičius showed clearly who was the true leader in the club. Moreover, Griškevičius banned hunting by the

${ }^{38}$ Interview by S. Grybkauskas with V. Kazanavičius.

${ }^{39}$ Ibid. 
members of the club without his knowledge. In the recollections of Astrauskas, when travelling to the coast, A. Drobnys asked him, as the chairman of the club, for permission to hunt, but he advised Drobnys to ask Griškevičius himself for permission. The planning committee chairman at that time expressed his anger: allegedly as the leader of the club, Astrauskas could assume greater responsibilities.

Drobnys experienced the 'discipline' of Griškevičius more than once. In the recollections of Astrauskas, he arrived drunk at one hunt with the Lithuanian SSR KGB chairman Petkevičius, and they were 'sent packing' from the forest by the first secretary. Of course, we can also see here security requirements, but assigning the punishment increased the power of the one who yielded it, i.e. Griškevičius.

In fact, in the hunt, inexplicable, and therefore it would seem funny, situations would occur that today have already become myths. For example, according to the contention of Z. Dokšas, the former director of a famous state farm, during one hunt a cat was dressed in the fur of a rabbit and, scared by the shots, it jumped high up a tree, greatly astonishing the government hunting people. The stories of the hunters reveal how important it was for participants in a hunt to appear as marksmen. There is a story about Astrauskas, during a driven hunt, standing in a line next to Griškevičius. He observed an old wolf sneaking out from the forest, and fired. Turning to Griškevičius, he asked, 'Why did you not shoot at the wolf?' To which the latter replied, 'I do not shoot at dogs.' However, after the gamekeepers announced that they had found a wolf and asked who shot it, Griškevičius instantly claimed the catch himself, saying 'I shot it,' thus surprising Astrauskas a great deal. Shooting a wolf was considered a great honour, because the animal is cunning and rarely falls into the traps of hunters. Therefore, the other participants in the hunt had to convince Astrauskas, unwilling to recognise an obvious untruth, to concede wisely to Griškevičius.

Equally serious conflicts also occurred in the second club. As Astrauskas writes in his memoirs, returning once after a hunt, J. Vildžiūnas and F. Bieliauskas, 'having drunk too much', attacked Charazov, calling him a protégé of Moscow. Bystanders managed to appease them, but the infuriated second secretary reiterated that he would not forget this attack, that he had considered Vildžiūnas and Bieliauskas to be internationalists, but they appeared as nationalists, and therefore it would be necessary to consider them for misconduct to the Party. 
Concluding Remarks: The Nomenklatura between Unity and Fragmentation

We have to agree with the statements of Willerton about the aspirations of Griškevičius to build a personal network of government. Nevertheless, the situation in Soviet Lithuania, which did not have significant political autonomy, only reminds us of individual moments in the processes occurring in Moscow, but its reflection was not exactly reduced. It is necessary to take several circumstances into account. First, Griškevičius inherited the post after many years of the leadership of Sniečkus. After several decades of his leadership, a club of leaders loyal to Sniečkus was formed, and it did not want to give up its influence in the management of the republic. These people from the Sniečkus environment determined to a great extent that the unacceptable Juozas Maniušis the chairman of the Council of Ministers, speaking Lithuanian poorly and maintaining close contacts with Moscow functionaries, would not be elected to the first post. ${ }^{40}$ The initiative to block the appointment of Maniušis, acting through Kazimieras Liaudis, who had close ties with Brezhnev and the Dnepropetrovsk clan, came from the active LCP CC members who were formally from a different level of the nomenklatura (from the chairman of the Presidium of the Lithuanian SSR Supreme Council M. Sumauskas, to the Lithuanian SSR State Radio and Television Committee chairman Jonas Januitis), but belonged to the same first club of hunters. In fact, in this way, it shows the unwillingness of the circle of the late leader Sniečkus to be smothered and ruled by the political tandem of Charazov and Maniušis, which certainly would have meant greater reliance by Lithuania on the centre. ${ }^{41}$

Griškevičius was not the obvious chosen leader of Moscow, or Sniečkus while he was still alive. Although he received the 'title' of first secretary from Moscow, just as important are under what circumstances this took place. He was elected first secretary after a long period, uncharacteristic for the appointment of leaders of the republics, and active engagement both by the Lithuanian nomenklatura and 'Governor General' Charazov.

${ }^{40}$ S. Grybkauskas, "The Role of the Second Party Secretary in the "election" of the first', Kritika: Exploration in Russian and Eurasian History, 14 (2013), no. 2, pp. 363-366.

${ }^{41}$ Ibid., p. 357. 
How was Griškevičius, who was not energetic, weak, and, according to his widow S. Griškevičienè, was fully satisfied with the office of head of the capital, able to gain and maintain political power and authority? Understandably, consolidating his authority in the Lithuanian nomenklatura, Griškevičius relied on 'the badge of government bestowed' by Moscow. Having chosen the leader of the republic, the CPSU CC apparatus consistently supported him, so he could easily transform the power given by Moscow into the development of his network of personal clients.

Nevertheless, the power 'given by Moscow' did not mean that the leader of the republic had secured unquestioned support. As can be seen from cases in other republics, intervention from the centre would increase particularly at a time when the leader of the republic was changed or replaced by a new leader. All-out reliance on the centre had its own limits, and could provoke dissatisfaction among the Lithuanian nomenklatura holding a particular position in relation to Moscow. It is doubtful that after its candidate was not elected LCP CC first secretary, the Lithuanian nomenklatura would be easily reconciled with the rapidly growing influence of the centre's institutions in the republic. The emerging internal disagreements and mutual complaints to Moscow, according to the informal ties of the Soviet bureaucracy investigating A. Ledeneva, were one of the most important circumstances determining the destruction of the ruling network existing in the periphery, which was collectively responsible for the political situation in the periphery, the so-called krugovaia poruka. $^{42}$ Therefore, Griškevčius could not rely solely on Moscow, he also needed recognition by the Lithuanian nomenklatura.

Hunting, which was an exceptional and most important informal activity of the highest Lithuanian nomenklatura, became an excellent platform for the new secretary to establish his authority in consolidating his clientele. By manipulating the composition of the most important first hunting club, to which people close to him and even his son Aloyzas were brought in, by inviting the functionaries supporting him to hunt (for example, LCP CC second secretary Dybenko), but ignoring possible contenders for informal leaders (e.g. Kharazov), Griškevičius took over control of the hunting by members of this club. He removed its informal leader Juozas Petkevičius from the duties of chairman of

${ }^{42}$ A. Ledeneva, 'The Genealogy of Krugovaia Poruka: Forced Trust as a Feature of Russian Political Culture', Trust and Democratic Transition in Post Communist Europe, ed. I. Markova (Oxford, 2004), p. 103. 
the club, appointing Astrauskas to the post and in the presence of the members of the club demonstrating to him who the real leader was.

Griškevičius introduced regulation, consolidating his authority. That is, he 'privatised' one of the most important informal power resources, hunting. Not only did the members of the nomenklatura have to obey Griškevičius during a hunt, they could not hunt individually, without his knowledge. In the recollections of Astrauskas, there was always a possibility to hunt alone, but there was a danger of being reproached by Griškevičius and other members of the circle for arbitrariness. According to Astrauskas,

Of course, [for example] Pakruojis [District Party Committee] first telephoned and invited one to hunt, [he said that] it was a good forest. But we did not do this, because all kinds of dissatisfaction arose. So you are hunting separately, expressing your own will. ${ }^{43}$

Thus, the informal life of the nomenklatura began to rely more on Griškevičius. The 'normalisation' of hunting was an effective strategy, which allowed Griškevičius to establish authority and power, limiting and restricting the potential grouping of the Lithuanian nomenklatura.

Even at first glance, 'childish' behaviour, unfairly claiming a catch for himself and thus becoming the informal leader, 'the king of the hunt', in this context of informal leadership, had a meaning and was symbolic. It seemed to echo the archetype of the leader of a primitive community of hunters and gatherers, entrenching the unity of formal and 'extracurricular' leadership. We can assert that with the Soviet federal set-up and management of an authoritarian nature, for Griškevičius it was worth accepting the proposal of the Lithuanian nomenklatura to become a hunter only when he succeeded in securing leadership status in this informal activity. He succeeded in doing this intelligently, 'keeping silent' and yielding to the other members of the club.

\section{Author Details}

Saulius Grybkauskas is a senior researcher at the Lithuanian Institute of History and the Institute of International Relations and Political Science. His research interests include: relations between the Kremlin and the Soviet republic nomenklaturas, nomenklatura social networks, Soviet nationalities policy, political economy of dictatorship.

Address: Lithuanian Institute of History, Kražių g. 5, Vilnius

Email: grybkauskas@istorija.lt

${ }^{43}$ Interview by S. Grybkauskas with V. Astrauskas. 
PETRO GRIŠKEVIČIAUS MEDŽIOKLĖS BŪRELIS

IR LIETUVIŠKOSIOS NOMENKLATŪROS KONSOLIDACIJA

Santrauka

\section{SAULIUS GRYBKAUSKAS}

Šiame straipsnyje daugiausia dèmesio skiriama neformalioms praktikoms, o konkrečiai - medžioklei, kuri buvo turbūt svarbiausias nomenklatūros ,užklasinis” užsièmimas. Medžioklè, išskirtinè ir svarbiausia aukščiausios lietuviškosios nomenklatūros neformali veikla, tapo puikia platforma naujajam sekretoriui P. Griškevičiui įtvirtinti savo autoritetą konsoliduojant nomenklatūrą, kuri buvo pakankamai fragmentuota po ilgamečio sovietinio Lietuvos vadovo A. Sniečkaus (1903-1974) mirties. Straipsnyje nagrinejjama valdžios medžioklès būrelių sudètis, jų organizavimas ir lyderysté šioje neformalioje veikloje. Teigiama, kad medžioklè pasitarnavo sovietinès lietuviškosios nomenklatūros interesams, nes ji leido tuometinès sovietinès respublikos lyderiui sustruktūrinti ir konsoliduoti savo klientūrą.

Manipuliuodamas svarbiausio - Pirmojo - medžioklès būrelio sudètimi - $\mathfrak{i}$ ji buvo priimti jam artimi žmonès, bet ignoruodamas galimus pretendentus ị neformalius lyderius, P. Griškevičius peremė šio būrelio narių medžiojimo kontrolę. Jis ịvedè Pirmojo nomenklatūros medžiotojų būrelio reglamentavimą. Medžioklès ,sunorminimas“ buvo veiksminga strategija, kuri leido P. Griškevičiui ịtvirtinti autoritetą ir galią, apriboti ir suvaržyti galimą lietuviškosios nomenklatūros grupavimąsi. Nomenklatūros konsolidavimas padèjo naujajam vadovui P. Griškevičiui ne tik ịsitvirtinti poste, bet ir mažino centro intervencijos ị respublikos valdymą galimybes. 